\title{
IMPLEMENTATION OF PERSONALITY COMPETENCE OF ISLAMIC RELIGIOUS EDUCATION TEACHERS IN THE INTEGRATED ISLAMIC ELEMENTARY SCHOOL SYARIF AR- RASYID ISLAMIC SCHOOL MEDANACADEMIC YEAR 2017/2018
}

\author{
Reza Noprial Lubis* \\ *Post Graduate of the FITK UIN SU Medan
}

\begin{abstract}
Personality competence is a skill or ability that must be possessed by someone, especially the teacher. Some of the competence of teachers is already owned by PAI teachers in Syarif Ar-Rasyid Islamic School Medan's Integrated Islamic Elementary School. But there are also those who have not implemented personality competence fully, as seen there are teachers who have not been mature, meaning that they cannot prioritize obligations over their personal interests, and there are still teachers who are not respected by their students and there are still teachers who seem indifferent to problems or problems faced by learners, and still appear to be undisciplined in the time or hours of entering class. This affects the personality of students at SDIT Syarif Ar-Rasyid Islamic School. Good or bad personal learners, depending on the good and bad personal teacher who guides them. This research is located at SDIT Syarif Ar-Rasyid Islamic School which is located at Jalan Menteng VII No. 186 Medan City. The type of research used is a type of qualitative research, namely the type of research that examines data that can describe complex and concrete social realities. Qualitative research is a research procedure that generates descriptive data about people through written or spoken words and observable behavior. The results of this study are that compliance with the Republic of Indonesia Law No. 14/2005 concerning Teachers and Lecturers at the Syarif Ar-Rasyid Islamic School Integrated Islamic Elementary School Medan. PAI teacher at SDIT Syarif Ar-Rasyid Islamic School has not met the standards as intended in the Law of the Republic of Indonesia Number 14 of 2005 concerning Teachers and Lecturers article 10 paragraph 1 . The indicators which have not been fully implemented namely; (1) a stable and stable personality; (2) mature person. There are also some additional indicators that exist in the PAI teacher at SDIT Syarif Ar-Rasyid Islamic School Medan, including: (1) devotion (doing Ibadan consistently); (2) attention to students; (3) getting along with students gently; (4) do not smoke.
\end{abstract}

Keywords: Personality Competence, Religious Education Teachers 


\section{INTRODUCTION}

Teacher competence has become a very important part lately, because teachers are key figures in the formation of the people aspired to the nation. The character of a teacher must include the competence of teachers as stipulated in the Law of the Republic of Indonesia Number 14 of 2005 concerning Teachers and Lecturers including: pedagogical competence, personality competence, social competence, and professional competence. (Law Number 14 of 2005 Concerning Teachers and Lecturers).

In connection with the above, the personality will determine whether the teacher will be a good educator and coach for his students or will be a destroyer and destroyer for the future of his students, especially for students who are still small (basic level) and students who are currently located at the intermediate level. In addition to a steady personality, Islamic Religious Education teachers must also have several characteristics, where these characteristics illustrate the abilities possessed by the teacher. For this reason, Islamic Education teachers must equip themselves with noble character. So that the position of the teacher does not decline, respect and appreciation of students towards the teacher does not decrease (Siahaan, Dissertation, 2016: 218).

Personality competence is a skill or ability that must be possessed by someone, especially the teacher. Teachers or Educators are highly demanded to have good quality personality competencies. This is because, teachers are an important element in educational institutions and in the learning process, especially in formal educational institutions. The teacher or educator is a central figure as well as a model that can be seen and emulated directly in its activities in the learning process and social activities in the sphere of education and in society (Argi Herriyan et al, Journal, 2017: 634).

The demands for personality are sometimes more severe than the demands of other professions. The phrase that is often heard: "Teachers are those that can be digugu and imitated" are often used as role models by the community, therefore teachers must recognize the values that exist in the community where the teacher lives or teaches. As an example, a teacher must have a personality that is idolized, his life is a perfect figure, that is the impression the teacher expects the community (Purwanti, Journal: 1074-1075). 


\section{THEORITICAL REVIEW}

Akmal Hawi competence comes from the English "competence" which means skills and abilities (Hawi, 2013: 1). Competence is also a combination of knowledge, skills, values, and attitudes that are reflected in the habits of thinking and acting.

Trianto said that competence is a person's ability both qualitatively and quantitatively. Competence is the ability, skills, and skills possessed by a person regarding their duties, positions and profession (Trianto, 2010: 53). Kunandar (2009: 55) which says that teacher competence is a set of mastery of abilities that must exist in teachers in order to realize their performance appropriately and effectively. According to Lubis (2010: 59), competence includes the skills to carry out tasks in an emergency, the skills to interact with the work environment, and cooperation with others, the skills to maintain health and safety.

Jaenudin (2012:116) says that personality is a characteristic or characteristic of a person that comes from the formations received from the environment. To understand what is meant by personality is not easy, because personality is so complex. The term personality in English is personality, derived from Greek, namely persona, which means mask, and personare which means to penetrate.

Koeswara (1991:11) Personality according to psychology is something that exists in individuals who guide and give direction to all individual behavior in question. Almost similar to what Littauer said, which gives the sense that personality is the overall behavior of an individual with a certain tendency system that interacts with a series of situations. So from that situation created in learning must be balanced with the habits and actions of a child, so there are feelings that are forced or depressed in children (Littaurer, 2006: 38).

According to Al-Rasyidin (2009:55), personality is interpersonal behavioral patterns that take place repeatedly into the character of human life, and the real form of the personality is in the behavior it displays. In other words it can be said that personalities are inherent and possessed traits of a person that arise from within him, but those inherent traits are influenced by the environment around a person as well.

Al Rasyidin (2009:118) says that there are several concepts that are closely related to personality, namely as follows: (1) Character (character), which is a description of behavior by highlighting values both explicitly and implicitly, (2) Temperament (temperament), namely personality that 
is closely related to biological or physiological determinants, (3) Traits (traits), i.e. a similar or equal response to a group of similar stimuli, lasting for a long time, (4) Type attribute (similar) by nature, but in a more limited stimulus group, and (5) Habit (habit), is the same response and tends to be repeated for the same stimulus.

Baharuddin (2007:209) mentions the core of personality is as follows: (1) that personality is a roundness consisting of physical and spiritual aspects, (2) that a person's personality is dynamic in relation to the environment, (3) that a person's personality is unique, different from others, (4) that the personality develops by being influenced by internal and external factors.

Furthermore, Yusuf and Nurihsan (2007:127) provide an understanding of personality in several elements, which are explained as follows: (1) dynamic organization, meaning that personality is always evolving and changing even though there is a binding and connecting organizational system as a component of personality, (2) psychophysical, this shows that personality is not merely natural (physical), but it is a combination of work between aspects and physicality in the unity of personality, (3) the term determines, means that personality contains determinations that play an active role in individual behavior, and (4) unique, this shows that no two people have the same personality.

Suprihatiningrum (2013:106) said that "Personality competence is a personal ability that reflects a steady personality, a stable personality, a mature personality, a wise and wise personality, an authoritative personality, an honest personality, a personality that is a role model for students, noble character ".

According to Muhammad Anas Ma'arif raised a number of competencies of PAI teachers according to Az-Zarnuji, including: (1) Wara and little food, (2) Serious and disciplined, jiddu wal muwadhobah, (3) Keeping ablution ', (4) ) Reading al-Qur'an by looking at, qiroatul Qur`ani nadron, and (5) evening prayers, qiyamul lail.

According to him, the five competencies of the intended PAI teacher are factors that influence the success or failure of learning activities. Therefore, teachers must pay attention to their competence to become teacher learners (Ma'arif, 2017: 5). 


\section{METHODS}

The type of data in this study is qualitative data through data collection from a natural setting by using the researcher as a key instrument. Data analysis procedures performed by data reduction, data presentation, and drawing conclusions are one of the qualitative data analysis techniques.

\section{RESEARCH RESULTS AND DISCUSSION}

Teachers as adult people who teach knowledge, skills and attitudes to students must have personality competencies. Personality ability is more concerned with the identity of a teacher as a person who is religious, moral, character and learner. Today's reality, it is often seen that teachers seem to ignore competencies about themselves as teachers, including personality competencies. Most teachers, more visible only complete their duties as a profession, without carrying out complete education. After learning with students, then they return to their activities in their home environment.

Teachers must be religious and moral. This is very important because teachers must help students become faithful, pious and noble people. If the teacher does not have faith, piety and noble character, it will be difficult to form students to have these characteristics. The second teacher must have a charismatic character. All of his attitudes show that he is wise and wise, steady, authoritative, sporty, mature and honest. This trait is very necessary to maintain the honor of the teacher and support the success of student learning. Students will tend to always follow adult humans who maintain their honor. Secondly, teachers are learners. The principle of lifelong learning must be held tightly so that the quality of teachers is not obsolete by the progress of time. Teachers must hold criticism, every criticism must be responded to positively.

Personality competencies are competencies that should exist in the teacher. Especially for Islamic Religious Education teachers or commonly referred to as PAI. The importance of the teaching profession makes the creation of standards governing teacher behavior. The application of personality comet is indeed considered important. Basically, the rules are made to be obeyed and what is certain is in order to improve in the future. In the Law of the Republic of Indonesia Number 14 of 2005 Concerning Teachers and Lecturers article 10 which states that: "Teacher competencies as referred to in Article 8 include pedagogical competencies, personality 
competencies, social competencies, and professional competencies obtained through professional education."

In connection with the above, a more detailed explanation of the Law of the Republic of Indonesia Number 14 of 2005 concerning Teachers and Lecturers can be seen in the explanation of paragraph 1, which reads as follows: "What is meant by personality competence is the ability of a steady, noble, wise personality, and authoritative and be an example of students. "

As for what is meant in the Law of the Republic of Indonesia Number 14 Year 2005 Regarding Teachers and Lecturers, it has been merged with what is meant by Kunandar who said that indicators of personality competencies include: steady and stable personality competencies; mature personality competence; wise personality competence; authoritative personality competence; and noble personal competencies that can be role models.

Based on the observations of researchers at the research location, the implementation of personality competencies carried out by PAI teachers has not been fully applied as intended in the Law of the Republic of Indonesia Number 14 of 2005 Regarding Teachers and Lecturers. The application of these competencies has not yet been carried out in a structured and structured manner. Personality has not been fully addressed. Teaching and learning activities carried out by teachers in carrying out their duties, must change from time to time in accordance with the times. Likewise, the teacher's personality. Without a change in personality, the teacher will be left behind, even worse than that. The need for a teacher to make changes in accordance with the times is something that must be considered. Awareness to change yourself towards a better course must be instilled in a teacher.

Personality derived from English "personality" which means charm or mask used by actors in every performance or game is deemed necessary to apply in the context of learning.In everyday life the word personality is used to describe our identity, identity, one's impression of ourselves or other people, healthy or problematic self functions. Personality is a characteristic of a person which is reflected in his daily behavior.

Throughout the observations made by researchers at the research location, the researchers saw that the behavior of PAI teachers seemed to be unchanged every day. The references contained in the Law of the Republic of Indonesia Number 14 of 2005 concerning Teachers and 
Lecturers as written above have not been the objectives of PAI teachers in implementing behavior or in attitude. This has an impact on the absence of change and the attitude of PAI teachers. Thus, it is felt necessary and requires special documents that study or study to find out how far the implementation of personality competencies is carried out by PAI teachers.

Through the study of documents conducted by researchers at the research location, namely at the Syarif Ar-Rasyid Islamic School Integrated Islamic Elementary School, researchers have not found documents related to the implementation of personality competencies, ranging from planning, implementing, to evaluating the personality competencies themselves. The Principal at the Integrated Islamic Elementary School Syarif Ar-Rasyid Islamic School also confirmed that this personality competency has not been structured, ranging from planning, implementation to evaluation of this competency.

In their daily activities at school, PAI teachers only behave with what they understand and what they know, without making the Law of the Republic of Indonesia Number 14 of 2005 concerning Teachers and Lecturers Number 14 of 2005 Concerning Teachers and Lecturers as a reference in acting and behave in a school environment. Thus, the Law used as a reference, certainly will not be known to what extent the implementation of personality competencies as a reference has been implemented or achieved. Then, it will affect the PAI teacher himself. Documents that should support the implementation of a program, should be presented in order to strengthen the implementation of an activity.

On the other hand, the researcher observed, during the process of teaching and learning activities, it was not seen that PAI teachers use the Learning Implementation Plan or Learning Implementation Plan as teaching material into the classroom. Thus, it can give the sense that the PAI teacher seems less prepared in carrying out learning. When researchers meet the Principal and ask about documents related to learning tools, researchers find documents in the form of Learning Kit Plans made by PAI teachers.

The learning implementation plan document was found in the principal's office. In an interview conducted with the school principal, he said that PAI teachers seemed often to be late in collecting documents such as the Learning Implementation Plan or RPP, Learning Syllabus, and so forth. This gives the meaning that, the PAI teacher does complete the 
assigned tasks, but sometimes it is too late in completion. Lesson Plans or lesson plans that should have been provided or provided at the beginning or before going to start learning, were actually completed at the end and even according to the Headmaster's statement until the end of the semester. Even though it was resolved, the PAI teacher did not carry out her overall personality competence, meaning that it had not fully met the standards set out in Law Number 14 of 2005 Concerning Teachers and Lecturers.

At the research location, researchers also found other documents that can be used as a study in the implementation of the personality competence of PAI teachers in the Syarif Ar-Rasyid Islamic School Integrated Islamic Elementary School Medan. The researcher found the attendance document of the teacher meeting. The document was found by researchers through the Administration room through a permit from the Administration. Researchers looked at two documents in the form of attendance list of PAI teacher meetings together with other schools on different days. Based on interviews and this document, the researchers concluded that in the teacher meeting activities, PAI teachers at the Syarif Ar-Rasyid Islamic School Integrated Islamic Elementary School in terms of attendance were considered good. PAI teachers rarely appear to be absent or absent from the meetings held by the school at the Syarif Ar-Rasyid Islamic School in Medan. The document provides an explanation that the PAI teacher is doing a good job in this meeting. By attending the teacher's meeting activities, it can give meaning that the PAI teacher is aware of or likes his profession as a teacher.

The above document means that the PAI teacher has carried out several personality competencies as intended in Law Number 14 of 2005 concerning Teachers and Lecturers. However, more attention is needed to be given to its implementation. PAI teachers need to look at the extent of implementing personality competencies in the future improvement efforts. With the lack of documentation regarding the fulfillment of the standards intended in Law Number 14 of 2005 Concerning Teachers and Lecturers, this means that this personality competency has not been given maximum attention.

From the results of the research and discussion above, it can be said that the PAI teacher does not yet fully possess or carry out a stable and stable personality. Then on the other hand, the PAI teacher also does not have a mature personality. Thus, PAI teachers in the Syarif Ar-Rasyid 
Islamic School Integrated Islamic Elementary School have not fully implemented or have the personality competencies as what is intended in the Law of the Republic of Indonesia Number 14 of 2005 Regarding Teachers and Lecturers. In other words, there has been no attempt made by PAI teachers to meet the standards given in the Law of the Republic of Indonesia Number 14 of 2005 concerning Teachers and Lecturers. Personality on a daily basis is just a personality without any changes in the future. It can be seen that the PAI teacher has not yet conducted a written assessment as a document to find out the achievements of the personality competency reference in accordance with applicable laws. So far, the PAI teacher in carrying out their duties shows that their personal competence is only part of what is intended in the Law of the Republic of Indonesia Number 14 of 2005 Concerning Teachers and Lecturers.

Emphasis on personality or behavior is indeed considered important, so that the teacher's motto whose behavior and behavior are innocent and imitated, remains attached to a teacher's self. In an effort to fulfill this competency, a special study is needed in writing to monitor the activities carried out. Therefore, documents are very much needed in the effort to carry out the evaluation.

The results of observations and research, it can be seen that the PAI teacher at SDIT Syarif Ar-Rasyid Islamic School does not yet have a stable and stable personality. This can be seen from the aspect of day-to-day and PAI teachers in teaching and learning activities. Sometimes the PAI teacher still looks late when he enters the classroom for his study hours. PAI teachers should be timely in carrying out their duties. The delay in the PAI teacher entering the class is due to his personal activities which take up his time. He often discussed with other subject teachers in the Teacher's Room. Thus, the PAI teacher has not referred to what Kunandar 2009: 7576) said in the section "having consistency in acting according to norms."

PAI teachers at SDIT Syarif Ar-Rasyid Islamic School in carrying out adult personalities, have not fully implemented adult personality competencies as intended in the Law of the Republic of Indonesia Number 14 of 2005 Concerning Teachers and Lecturers. It is said so, because it can be seen from the completion of the task as a teacher, namely completing the Learning Implementation Plan or Learning Implementation Plan. In its completion, he was always late in his collection. Learning Implementation Plan or commonly referred to as Learning Implementation Plan is the key for teachers in their daily teaching activities. Teachers without a Learning 
Implementation Plan will have an impact on learning that is more easily tossed around.

\section{Conclusions and Recommendations}

The conclusions that can be drawn are: (1) fulfillment of the standards of the Law of the Republic of Indonesia Number 14 of 2005 concerning Teachers and Lecturers in the Integrated Islamic Elementary School Syarif Ar-Rasyid Islamic School Medan, as for personality competence is a strong personality ability, noble character, wise, and authoritative and be an example of students. The findings and discussion, PAI teachers at SDIT Syarif Ar-Rasyid Islamic School have not met the full standards of steady and stable personalities, then mature individuals, (2) PAI teacher's personality is stable and stable, mature, wise, authoritative, noble and can be an example in SDIT Syarif Ar-Rasyid Islamic School can be seen from the behavior of PAI teachers in the school environment and (3) the application of the personality competence of PAI teachers in SDIT Syarif Ar-Rasyid Islamic School is considered good. At least, there are three sub-indicators of personality competencies that can be implemented, namely the personality of a wise PAI teacher, the personality of an authoritative PAI teacher and the personality of a PAI teacher who is noble and can be an example. There are also some additional indicators that exist in the PAI teacher at SDIT Syarif Ar-Rasyid Islamic School Medan, including: devotion (doing Ibadan consistently); attention to students; associate with students gently; do not smoke.

Recommendations that can be useful for several parties include: (1) for the foundation to be able to improve programs related to improving teacher personality competencies. So that with a good teacher's personality, the program will also improve, (2) for principals to take part in monitoring developments by structuring evaluations of the teacher's personality in the school environment. Thus, it will be able to make a better program for increasing the personal competence of teachers, (3) for educators to always improve themselves towards a better. Because the teacher is an innocent and imitated figure, and (4) the next morning the next researcher for further researchers can carry out further research with broader development. 


\section{REFERENCES}

Al-Rasyidin. (2009). Percikan Pemikiran Pendidikan Dari Filsafat Hingga Praktik Pendidikan. Bandung: Citapustaka Media Perintis.

Azra, Azyumardi. (1999). Pendidikan Islam: Tradisi dan Modernisasi Menuju Milenium Baru. Jakarta: Logos Wacana Ilmu.

Karya.

Baharuddin. (2007). Psikologi Pendidikan-Refleksi Teoretis Terhadap Fenomena. Jogjakarta: Ar Ruzz Media,.

Hawi, Akmal. (2013). Kompetensi Guru Pendidikan Agama Islam. Jakarta: Raja Grafindo Persada.

Herriyan, Argi dkk. (2017). Jurnal. Kompetensi Kepribadian Guru Pendidikan Agama Islam Dalam Membina Akhlak Peserta Didik di Mas Proyek Univa Medan. Edu Riligia, Vol. 1 No. 4 September-Desember 2017.

Jaenudin, Ujam. (2012). Psikologi Kepribadian. Bandung: Pustaka Setia. Kasiram, Moh.(2008). Metodologi Penelitian. Malang: UIN-Malang Press.

Koeswara, E. (1991). Teori-Teori Kepribadian: Psikoanalisis, Behaviorisme, Humanistik. Bandung: Eresco.

Lubis, Syaiful Akhyar. (2010). Profesi Keguruan. Bandung: Cita Pustaka.

Maarif, Institut Pesantren KH Abdul Chalim Pacet Mojokerto, Volume 2, Nomor 2, Januari-Juni 2017.

Rusydi Ananda. (2019) Perencanaan Pembelajaran. Medan: LPPPI, .

Siahaan, Amiruddin. (2016). Profesionalitas Guru Menurut M. Quraish Shihab dalam Tafsir Al Mishbah. Disertasi Doktor. Pascasarjana Universitas Islam Negeri Sumatera Utara. Medan.

Suprihatiningrum, Jamil. (2013). Guru Profesional: Pedoman Kinerja, Kualifikasi, dan Kompetensi Guru.Jakarta: Ar-Ruzz Media.

Yusuf dan Nurihsan. (2007). Teori Kepribadian.Bandung: Remaja Rosdakarya. 